January

\title{
SUBSTITUTES OR COMPLEMENTS: FORMAL AND INFOMRL CREDIT DEMAND BY MAIZE FARMERS IN ASHANTI AND BRONG AHAFO REGIONS OF GHANA
}

\author{
Dadson Awunyo-Vitor ${ }^{1}$ and Vincent Abankwah ${ }^{2}$
}

\begin{abstract}
This study examines credit demand by maize farmers and analysed factors influencing their use of informal and formal credit. The analysis is based on data collected from a survey of 590 maize farmers in seven districts of Ashanti and Brong Ahafo Regions of Ghana during May-July 2010. Descriptive statistics, probit and bivariate probit models were used to analyse the data. The study revealed informal credit sources for maize farmers as relatives and friends, traders and private money lenders. Maize traders are major players in the informal credit market followed by agricultural input sellers. Among the formal sources rural banks are the most prominent. Regional location, Gender, engagement in other economic activities and the level of agricultural commercialisation were observed to be factors that influence farmers' demand for informal credit. In addition to these factors, farmer years of education and proximity to financial institution influence demand for formal credit. The result of the bivariate probit suggests that formal and informal credits are not necessarily perfect substitutes but they complement each other to provide credit needs of farmers in maize production.
\end{abstract}

Keywords: maize farmers, informal credit, formal credit, probit, bivariate probit

\section{INTRODUCTION}

The rural financial market in developing countries is composed of formal, semiformal and informal financial institution (Hussain and Demaine 1992; Steel and Andah 2005). Ghate (1992) defined formal financial services providers as registered companies that are licensed to offer financial services by Central Monetary Authority. He asserted that these institutions are largely urban based in terms of distribution of branches and the concentration of deposit and lending activities.
According to Kashuliza et al (1998) informal financial services refers to all transaction, loans and deposits that take place outside the regulated monetary system this include activities of intermediaries such as relatives and friends, traders, money lenders. Semiformal institutors are described by Steel and Andah (2005) as institutions which are registered to provide financial services and are not controlled by central monetary authority.

\footnotetext{
${ }^{1}$ Department of Agricultural Economics, Agribusiness and Extension, Kwame Nkrumah University of Science and Technology, Kumasi, Ghana

${ }^{2}$ Department of Agricultural Economics and Extension Education, University of Education, Winneba, Ghana
} 
The Journal of Agricultural Science, 2012 vol. 7, no 1

\begin{tabular}{ll}
\hline $\begin{array}{l}\text { Khandker and Faruqee (2003) noted } \\
\text { that informal credit is largely used for }\end{array}$ & $\begin{array}{l}\text { formal financial sector informal } \\
\text { financial services is still active. } \\
\text { consumption and it's not large enough } \\
\text { to spur investment and growth. ISSER, }\end{array}$ \\
$\begin{array}{l}\text { The aim of this study is to identify } \\
\text { impos has, therefore reiterated the }\end{array}$ & $\begin{array}{l}\text { actors within the financial market in the } \\
\text { importance of formal credit to }\end{array}$ \\
$\begin{array}{l}\text { accelerate the development of the } \\
\text { priority areas including industries and }\end{array}$ & $\begin{array}{l}\text { Ghana and factors influencing maize } \\
\text { farmers demand for formal and }\end{array}$ \\
agriculture through increased & informal credit and evaluate if their \\
productivity in the agricultural sector. & demand for these credit forms are \\
The central monetary authority (Bank of & complement or substitute.
\end{tabular}

Ghana) has adopted a number of policies, which aimed at increasing formal intermediation in order to increase farmers' access to formal credit (Ekumah and Essel, 2001). These include interest rate control and credit ceiling. This followed from the perception that low interest rates would induce investment, which in turn would increase output and employment and subsequently, lead to higher savings (Aryeetey and Hyuha, 1991). However, these policies rather led to a distortion of the markets. Formal financial institutions have increased in numbers and capitalisation. Non-Bank financial institution have emerged especially savings and Loans Companies (BOG, 2007). Despite these developments, a study on the progress of implementation of Ghana Poverty Reduction Strategy II (GPRS II) revealed that, large proportion of the rural household tend to demand informal credit. According to Asiedu-Mante (2005) and Steiner (2008) the formal financial institutions are unable to satisfy credit needs of rural folks, thus they tend to use informal credit which are often unsatisfactory, as they carry high interest rate. Aryetey (2008) also noted that despite the development in the

\section{MATERIAS AND METHODS}

\section{Data Sampling Method}

Multistage sampling was conducted to select 2 regions, 7 districts and 590 farmers for the study. Selection of the regions and districts was guided by the level of agricultural activities and the level of maize production using official statistics from Ministry of Food and Agriculture, MoFA (2009). In Ashanti Region, districts whose maize production output in 2008 exceeded 20,000 metric tonnes were 2 which were selected while in Brong Ahafo Region, the 5 districts which had a minimum of 27,000 metric tonnes each of maize output in 2008 were selected for the study. Table 01 indicates selected districts, level of maize production and number of farmers sampled from each district in the two selected regions. A third stage sampling involved identifying and listing of maize farmers in the operational area. Selection of respondents was guided by their involvement in maize production. A total size of 590 maize farmers from the study area was sampled for the study. A questionnaire was administered to sample farmers engaged in maize production. The survey questionnaire 
Dadson Awunyo-Vitor and Vincent Abankwah

contained detailed sections on vector of explanatory variables
demographic and socioeconomic $\left(X_{i}\right)$ include individual and household characteristics of the farmers, household characteristics, household assets and the farmers' attitudes towards formal and informal credit.

\section{Analytical Framework}

Data analysis followed a two-prong approach by making use of both qualitative and quantitative techniques. For the qualitative analysis, descriptive statistics such as percentages, and frequencies were used. Descriptive analysis was undertaken to identify and list all sources from which maize farmers seek financial services. Quantitative analysis used by Okurunt et al. (2004) and Mohieldin and Wright (2000) was adopted and modified to evaluate factors that influence maize farmers' demand for formal and informal credit.

A decision by respondents to demand credit (informal or formal) is assumed to be influenced by the individual and household characteristics as well as institutional factors. Let represent farmers' decision to demand credit by a latent variable $\left(Y_{i}\right)$. This depends on a characteristics as well as institutional factors. This leads to qualitative response model which can be presented as: $Y_{i}=\alpha+\beta^{i} X_{i}+\mu_{i}$.

The farmer's decision to demand or not to demand credit $Y_{\tilde{i}}$ is assumed to be dependent on his assessment of the marginal cost and benefits associated with the use and non-use of credit from these sources respectively. Based on his assessment s/he may decide to demand or not to demand credit. In reality we do not observe this marginal cost and benefit hence dependent variable $Y_{\tilde{i}}$ in equation 1 is unobservable. -Thus Equation 1 cannot be estimated as $Y_{i}$ is not observed. One can only observe whether respondent demand credit or not through the survey questionnaire. Hence we defined another variable $Y^{*}$ that leads to a binary outcome for the dependent variable such that:

$Y^{*}=1$ if respondent demand credit,

$Y^{*}=0$ if respondent does not demand credit

Table 01: Selected district and sample size

\begin{tabular}{lllc}
\hline Region & \multicolumn{1}{c}{ Districts } & $\begin{array}{c}\text { Maize output in } \\
\text { Metric tonnes }\end{array}$ & $\begin{array}{c}\text { Sample size selected } \\
\text { from each district }\end{array}$ \\
\hline Ashanti & Afigya-Sekyere & 23,401 & 53 \\
& EjuraSekye-dumase & 21,871 & 30 \\
Brong & Sunyani & 43,153 & 93 \\
Ahafo & Dormaa & 72,270 & 121 \\
& Techiman & 27,500 & 110 \\
& Nkoranza & 74,719 & 95 \\
& Kintampo & 73,308 & 88 \\
& Total & 336,22 & 590 \\
\hline
\end{tabular}

Source: MoFA, 2009 
The Journal of Agricultural Science, $2012 \mathrm{vol}$. 7, no 1

There are several methods that can be used to analyse data involving binary outcomes. Linear Probability Model (LPM), probit and logit models can be used to analyse household's qualitative response or which give rise to binary choice models. If the independent variables are normally distributed the discriminant analysis estimate which follows Ordinary Least Square (OLS) is the true Maximum Likelihood Estimate (MLE) and therefore asymptotically more efficient than the probit and logit models which require Maximum Likelihood method. However, if the independent variable is not normally distributed the discriminant analysis estimate is not consistent, whereas the probit and logit MLE are consistent and therefore more robust (Maddala, 1983; Amemiya, 1981; Cameron and Travedi, 2005). The LPM can be used to analyse binary models such as the one under $y_{1 i}^{*}=\beta_{1}^{*} x_{1 i}+\varepsilon_{1 i} y_{1 i} \begin{cases}1 & y_{1 i}^{*} \geq 0 \\ 0 & y_{1 i}^{*}<0\end{cases}$

2

$$
y_{2 i}^{*}=\beta_{2}^{*} x_{2 i}+\varepsilon_{2 i} y_{2 i} \begin{cases}1 & y_{2 i}^{*} \geq 0 \\ 0 & y_{2 i}^{*}<0\end{cases}
$$

3

\section{$\left(\varepsilon_{1 P}, \varepsilon_{2 I}\right) \sim B V N(0,0,1,1 \rho)$}

4 consideration. Though, Pindyck and Rubinfeld (1981), Amemiya (1981) and Gujarati (1988) have noted that LPM can be used to analyse binary models such as the one under consideration it has serious defect in that, the estimated probability values can lie outside the normal 0-1 range. Hence probit and logit models are advantageous over LPM since the probability values are bound between 0 and 1. Due to the above shortcomings of the OLS and LPM, in the analysis of studies involving qualitative choices, probit model is selected for the analysis of factors influencing demand for credit. In order to assess more formally if informal and formal credits are substitutes or compliments we followed Mohieldin and Wright (2000) by using bivariate probit model, with the following econometric specifications;

Where, for the purpose of our model,

$y_{1 i}^{*}=$ propensity of a farmer to demand or use formal credit

$y_{1 i}=$ observed farmers who demand or use formal credit

$y_{2 i}^{*}=$ Propensity of a farmer to demand or use informal credit

$y_{2 i}=$ observed farmers who demand or use informal credit

$x_{1 i}$ and $x_{2 i}=$ list of explanatory variables with $\beta_{1}^{*}$ and $\beta_{2}^{*}$ being their associated

parameter vectors; and

$\varepsilon_{1 i}$ and $\varepsilon_{2 i}=$ random error terms that are jointly bivariate normal (BVN). 
Dadson Awunyo-Vitor and Vincent Abankwah

In this case each farmer is assumed to possess a propensity to demand formal credit $\left(y_{1 i}^{*}\right)$ and although this is not directly observable, when the propensity becomes positive (ie greater than zero) then the farmer is observed to demand formal credit. This is identical to the standard latent variable approach for probit model. However, in the bivariate probit model framework, the farmer is assumed to possess a propensity to demand informal credit $\left(y_{2 i}^{*}\right)$, which again is observed if the propensity is positive. It is possible that the propensity to demand formal and informal credit may not be independent; therefore, we allow the random error of the informal credit and the formal credit demand equations to be correlated (with correlation coefficient).

\section{RESULTS AND DISCUSSION}

\section{Informal credit source}

There are four major intermediaries operating in the informal financial market segment as is evident in Table 02. These are relatives and friends; agricultural input traders; maize traders, and private money lenders. Traders are

Table 02: Informal credit intermediaries the most important source of informal credit, about $37 \%$ and $24 \%$ of the farmers demand credit from maize traders and input traders respectively. Focus group discussion revealed that some of the traders interlink their credit with supply of input or purchase of maize.

Table 02 shows that relatives and friends are the second most important source of informal credit. Relatives and friends offer credit to farmers at negotiable rates depending on social relationships and reputation. Farmers who are capable of building social capital take advantage of this form of loan. Private money lenders tend to play less significant role in servicing the financial needs of farmers in the study area. Focus group discussion revealed that the modus operandi of money lenders is such that credit applicants are required to provide some collateral securities or guarantor who would pledge to repay the loan and interest in case of default. This requirement coupled with the risky perception of rain-fed agriculture and loan recovery procedures deters farmers from seeking credit from money lenders.

\begin{tabular}{lcc}
\hline \multicolumn{1}{c}{ Intermediaries } & Frequency & Percentage \\
\hline Relatives and Friends & 69 & 31 \\
Agricultural input traders & 52 & 24 \\
Maize traders & 82 & 37 \\
Private money lenders & 18 & 8 \\
\hline Total & 221 & 100 \\
\hline
\end{tabular}

Source: survey data, 2010 
The Journal of Agricultural Science, 2012 vol. 7, no 1

\section{Table 03: Formal credit sources}

\begin{tabular}{lll}
\hline Source & Frequency & Percentage \\
\hline Universal banks & 92 & 25 \\
Rural banks & 188 & 51 \\
Savings and Loans company & 35 & 9 \\
Credit union & 54 & 15 \\
\hline Total & 369 & 100 \\
\hline Source: Survey data, 2010 & &
\end{tabular}

\section{Formal credit source}

The study categorised institution operating within the formal financial market segment into three (3) major classes namely: Universal banks, Rural banks, Savings and loan company and credit union. Table 03 shows the relative prominence of the classes of institutions in advancing credit to farmers.

The rural banks play a leading role in offering credit to farmers. More than half, $51 \%$, of the farmers used rural banks as a source of formal credit. Rural banks have the most extensive network of deposit taking and credit facilities in each of the study districts. Hence the farmers' have close proximity to rural banks. The next prominent source of agricultural credit is universal banks, basically the Agricultural Development Bank (ADB). Though, ADB has the mandate of offering agricultural credit to farmers, only a quarter of the farmers demand credit from this bank because of its limited network within rural Ghana. Although the activities of non-bank financial institutions in the study area have seen remarkable improvement over the years in terms of number of institutions and branch networks, most of them do not offer agricultural credit.
Table 03 shows only $9 \%$ and $15 \%$ of the farmers demand credit from savings and Loans Companies and credit unions respectively.

\section{Determinants of farmers' demand for informal credit}

The result of the factors influencing demand for informal credit is presented in Table 04 . Out of the 11 variables 4 of them have significant relationship with demand for informal credit. Regional location and age exhibit positive and significant relationship with demand for informal credit. However, the coefficients of farmer's perception of formal institution lending procedure and proximity to formal financial institution exhibit expected sign but statistically insignificant.

Regional location has positive and significant effect on demand for informal credit. This implies that respondents in the Ashanti region are more likely to demand informal credit as compared with their counterparts in Brong Ahafo Region. The reason for this observation might be the fact that there are vibrant maize market centers in each of the study districts within Ashanti Region. These markets are made up of traders who, as has been 
Dadson Awunyo-Vitor and Vincent Abankwah

established in Table 01, are prominent in offering informal credit to farmers.

Gender of the farmer has positive and significant relationship with use of informal credit market. Males are more likely to demand informal credit as compared to their female counterparts. This may be attributed to the fact that women control few assets, cultivate smaller acreages with low productivity. Thus traders who are the major players in the informal credit market tend to shy away from women farmers.

Engagement in other economic activities exhibit positive and significant relationship with demand for informal credit. Farmers, at times, need short term finance for example within weeks which the informal market segment is better able to satisfy compared to formal market which do not offer such products. In addition, most lenders see loan repayment by farmers who engage in other income generating activities as more probable hence tend to favors them.

In the case of agricultural commercialization, the coefficient is positive and significant at $1 \%$ level. The implication is that as traders offer interlinked credit to farmers and enhance their businesses they would tend to favors those who produce for market. Thus the larger the proportion of produce sold by the farmer, the more likely the farmer is to demand informal credit.

\section{Determinants of farmers' demand for formal credit}

The regression results concerning the farmers' demand for formal credit are presented in Table 05. The results indicate significant relationship between demand and regional locations, gender, other economic activities, value of total asset, years of education, and proximity to financial institution.

Regional locations have a negative and significant relationship with demand for formal credit by the respondents. These results indicate that farmers in Ashanti Region are less likely to demand formal credit as compared to those in Brong Ahafo Region. This can be attributed to the availability of informal credit from traders as there are more vibrant maize markets in the region compared to study districts within Brong Ahafo Region.

Gender of the farmer has positive and significant relationship with demand for formal credit. Thus male farmers are more likely to demand formal credit as compared to their female counterparts. This confirms the result of Zeller (1994) when he observed that women in Madagascar are less likely to demand credit from formal financial institutions compared to male. In addition Steiner (2008) in a related study in Ghana observes that female headed households are less likely to demand formal credit. Though, gender positively and significantly influence demand for both formal and informal credit its marginal effect on formal credit (9\%) is stronger than informal (5\%). This is because women control few assets, cultivate smaller acreages with low productivity and this does not give them collateral security which is one of the major requirements for formal credit. 
The Journal of Agricultural Science, 2012 vol. 7, no 1

Table 04: Probit Estimate for determinants of farmers demand for formal credit

\begin{tabular}{|c|c|c|c|}
\hline Independent Variables & Coefficient $t$ & t-statistic & $\begin{array}{c}\text { Marginal } \\
\text { Effect }\end{array}$ \\
\hline $\begin{array}{l}\text { Regional Location of the respondents(Dummy }=1 \\
\text { if in Ashanti Region) }\end{array}$ & $-0.308 *$ & -1.835 & -0.116 \\
\hline Gender (Dummy $=1$ if male $)$ & $0.229 *$ & 1.735 & 0.090 \\
\hline Age in years & 0.036 & 0.782 & 0.014 \\
\hline $\begin{array}{l}\text { Other economic activities (Dummy }=1 \text { if engaged } \\
\text { in other economic activities) }\end{array}$ & $0.312 * *$ & 2.469 & 0.122 \\
\hline Value of total asset & $0.001 * *$ & 2.554 & - \\
\hline $\begin{array}{l}\text { Proximity to financial institution (Dummy }=1 \text { if }> \\
2 \mathrm{~km} \text { from formal financial institution) }\end{array}$ & $0.531 * * *$ & 3.876 & 0.197 \\
\hline $\begin{array}{l}\text { Attitudes towards Risk (Dummy }=1 \text { if positive } \\
\text { attitude towards risk) }\end{array}$ & -0.099 & -0.807 & -0.038 \\
\hline Value of maize output & $-1.6 \mathrm{E}-05$ & -0.606 & - \\
\hline Dependency ratio & -0.055 & -0.453 & -0.022 \\
\hline Age in years Square & -0.002 & -0.520 & -0.000 \\
\hline Number of years of schooling & $0.057 * * *$ & 5.000 & 0.022 \\
\hline Cons & -1.889 & -1.765 & \\
\hline Log likelihood $=-363.41525$ & $\begin{array}{l}\text { Number of obs } \\
\text { LR chi2(11) } \\
\text { Prob > chi2 } \\
\text { Pseudo R2 }\end{array}$ & $\begin{aligned} s= & 590 \\
= & 86.84 \\
= & 0.0000 \\
& =\quad 0.1067\end{aligned}$ & \\
\hline
\end{tabular}

*** is significant at $1 \%$, ** significant at $5 \%$ and $*$ is significant at $10 \%$

The result indicates positive and significant relationship between engagement in other income generating activities and demand for formal credit. Lenders are aware that in case of crop failure income from these sources can be used to defray the loan. Engagement in other income generating activities has effect on demand for both informal and formal credits. However, its marginal effect $(12 \%)$ on demand for formal credit is more than twice (5\%) the effect on informal credit demand. This observation stems from the fact that engagement in other income generating activities serve as surety for loan repayment for formal financial institutions since granting and recovery of loans is not based on social relationship and reputation as it is with the informal credit delivery. 
Dadson Awunyo-Vitor and Vincent Abankwah

Even though, value of farmer asset does not influence demand for informal credit as indicated in Table 04, it has a positive and significant influence on demand for formal credit shown in Table 05. This is because while granting of informal credit is largely based on social reputation and relationship, delivery of formal credit is primarily based on collateral security which is enhanced by acquisition of assets.

Distance to the nearest formal institution (proximity) had positive and significant relationship with demand for formal credit. This imply that the shorter the distance to the formal institution the greater the likelihood of farmer demanding formal credit. Therefore increasing availability of formal institution resulting in easy access has greater likelihood of increasing demand for formal credit. This observation supports the result of a study by Zeller (1994) and Bee (2007) on demand for formal credit which indicated that proximity has positive and significant relationship with demand for formal credit.

Though demand for informal credit is not significantly influenced by farmer's years of education as exhibited in Table 03 , there exist a positive and significant relationship between farmer's demand for formal credit and his/her years of education. The positive coefficient was expected as it was believed that farmer's decision to demand formal credit improves with increased level of education as they are able to understand and follow policies and procedures of these institutions. In a related study Bee (2007) found level of education to be significantly related to demand for formal credit in Tanzania. The implication of these results is that formal institutions in the study do not target uneducated farmers and that majority of those who have benefited from their credit had some formal education.

\section{Formal and informal credit compared: Substitutes or compliments?}

Tables 02 and 03 indicate that formal financial institutions are the major sources of agricultural credit as more than half of the farmers demand formal credit. In a focus group discussion the respondents noted that formal sources tend not to satisfy their demand as they could not provide required information and collateral to support the amount of loan they need. Also they argued that the informal sources cannot provide the loan amount demanded as the operators have limited resources. Hence the need to complement formal credit with informal credit.

From the bivariate probit results in Table 06, the interaction effect between demand for informal and formal credit appear to be very small as indicated by the robustness of the signs and size of the coefficients across specifications. The coefficient for regional location, engagement in other economic activities and agricultural commercialization are positive and statistically different from zero for demand for credit from informal and formal sources. This indicates that increased demand for formal credit caused by the variables would not reduce demand for informal credit since demand for both formal and informal credit is significantly influenced by the variables in the same manner. This observation suggests that 
The Journal of Agricultural Science, 2012 vol. 7, no 1

the two forms of credit are of the formal market segment as well as complementary rather than substitutes. literacy level of the farmers have Proximity (distance from residence to positive and significant coefficient for formal financial institution), total demand for formal credit.

household asset, operational modalities

Table 05: Results of bivariate probit model

\begin{tabular}{|c|c|c|}
\hline Independent Variables & Formal & Informal \\
\hline $\begin{array}{l}\text { Regional Location of the respondents(Dummy } \\
=1 \text { if in Ashanti Region) }\end{array}$ & $\begin{array}{l}0.468 * * * \\
(2.715)\end{array}$ & $\begin{array}{c}1.585^{* * * *} \\
(5.840)\end{array}$ \\
\hline Gender (Dummy $=1$ if male) & $\begin{array}{c}0.182 \\
(1.320)\end{array}$ & $\begin{array}{l}0.242 * \\
(1.809)\end{array}$ \\
\hline Age in years & $\begin{array}{c}0.003 \\
(0.052)\end{array}$ & $\begin{array}{c}-0.055 \\
(-1.153)\end{array}$ \\
\hline $\begin{array}{l}\text { Other economic activities (Dummy }=1 \text { if } \\
\text { engaged in other economic activities) }\end{array}$ & $\begin{array}{l}0.357 * * * \\
(2.667)\end{array}$ & $\begin{array}{r}0.290 * * \\
(2.215)\end{array}$ \\
\hline Value of total asset & $\begin{array}{c}1.8 \mathrm{E} 4 * * * \\
(2.590)\end{array}$ & $\begin{array}{l}-1.04 \mathrm{E} 5 \\
(-1.132)\end{array}$ \\
\hline $\begin{array}{l}\text { Proximity to financial institution (Dummy }=1 \text { if } \\
>2 \mathrm{~km} \text { from formal financial institution) }\end{array}$ & $\begin{array}{l}0.433 * * * \\
(2.988)\end{array}$ & $\begin{array}{r}0.185^{* * * *} \\
(13.883)\end{array}$ \\
\hline Age in years Square & $\begin{array}{l}7.74 \mathrm{E} 5 \\
(0.144)\end{array}$ & $\begin{array}{c}6.6 \mathrm{E} 4 \\
(1.260)\end{array}$ \\
\hline $\begin{array}{l}\text { Flexibility in Loan Repayment (Dummy }=1 \text { if } \\
\text { perceived to be flexible) }\end{array}$ & $\begin{array}{c}1.038 * * * \\
(3.763)\end{array}$ & $\begin{array}{l}-0.255 \\
(-1.149)\end{array}$ \\
\hline $\begin{array}{l}\text { Level of Agricultural commercialization } \\
\text { (Dummy }=1 \text { if sold more than } 70 \% \text { of produce) }\end{array}$ & $\begin{array}{l}0.311 * * \\
(2.174)\end{array}$ & $\begin{array}{c}0.489 * * * \\
(3.492)\end{array}$ \\
\hline Literacy level (Dummy $=1$ if literate ) & $\begin{array}{l}0.447 * * * \\
(3.662)\end{array}$ & $\begin{array}{c}0.139 \\
(-1.157)\end{array}$ \\
\hline _cons & $\begin{array}{l}-1.578 \\
(1.438)\end{array}$ & $\begin{array}{c}0.670 \\
(0.622)\end{array}$ \\
\hline
\end{tabular}

Log likelihood $=-668.2264 \quad$ Number of obs. $=590$

Prob $>$ chi $=0.0000 \quad$ Wald chi $^{2}(22)=183.25$

$* * *$ is significant at 1\%, ** significant at $5 \%$ and $*$ is significant at $10 \%$ t-statistics are in parentheses

Likelihood-ratio test of rho $(\rho)=0: \quad$ chi2 $(1)=.104912 \quad$ Prob $>$ chi2 $=0.7460$ 
The correlation coefficient $\rho$ is not statistically different from zero thus the result suggests that demand for formal and informal credit are not necessary perfect substitutes for maize farmers in the study area. This result support the findings of Mohieldin and Write (2000) when They concluded from their study on formal and informal financial sector in Egypt that these two source of credit are very imperfect substitute.

\section{CONCLUSIONS}

The study revealed informal credit sources for maize farmers as relatives and friends, traders and private money lenders. Maize traders are major players in the informal credit market followed by agricultural input sellers. The prominence of traders as source of informal credit is due to the fact that they interlink credit with purchase of maize and sale of inputs. Among the formal sources rural banks are the most important credit provider. The popularity and use of rural bank has been attributed to the large networked branches which enhance farmers' proximity and access to formal credit. Regional location, Gender, engagement in other economic activities and the level of agricultural commercialisation were observed to be factors that influence farmers' demand for informal credit. In addition to these factors, farmer years of education and proximity to financial institution influence demand for formal credit.

The result of the bivariate probit suggests that formal and informal credits are not necessarily perfect substitutes but they complement each other to provide credit needs of farmers in maize production.

Increasing the branch network of the formal credit institutions especially rural banks will improve access to and enhance farmer demand for formal credit. Encouraging farmers to undertake alternative livelihood activities will enhance their loan repayment capacity that empowers them to benefit from both formal and informal credit sources. Education is an important variable influencing demand for formal credit, hence farmers need to be educated on the credit policies and requires of the formal financial institutions. Given that informal credit is a complement to formal credit effort should be made to build capacity of intermediaries especially traders who are major players within the informal credit market. 
The Journal of Agricultural Science, 2012 vol. 7, no 1

\section{REFERENCES}

Amemiya, T. (1981). Qualitative Response Model: A Survey. Journal of Economic literature 19: 1483-1536.

Aryeetey, E. (1996). The Formal Financial Sector in Ghana after the Reforms. Working paper 86, Overseas Development Institute.

Aryeetey, E., Hyuha, R. (1991). The Informal Financial Sector and Markets in Africa: An Empirical Study. Economic Reform in Sub-Saharan Africa. In A. Chhibber and S. Fischer, (ed) A world Bank Symposium, Washington D. C.

Asiedu -Mante, E. (2005). Integrating Financial Services into Poverty Reduction Bank of Ghana (2007). Bank of Ghana Annual report, 2007.

Bee, K. F. (2007). Rural Financial Market in Tanzania: An analysis of access to financial services in Babati District, Manyara Regio. PhD Thesis, University of South Africa.

Cameron, C. A., Trivedi, P. K. (2005). Microeconometrics: Methods and Applications, Cambridge University Press. Pp. 463 - 569.

Ekumah, E. K., Essel, T. T. (2001). Gender Access to Credit under Ghana's financial sector reform: A case study of two rural banks in Central region of Ghana. IFLIP Research Paper No 01-4.

Ghate, P. B. (1992). "Interaction Between the Formal and Informal Financial Sectors: The Asian Experience", World Development, No. 1., XIV.

Gujarati, D. N. (1988). Basic Econometrics. 2nd edition. McGraw-Hill Book Company. New York.

Hussain, I., Demaine, H. (1992). How informal credit offers greater benefit to farmers: An inquiry into credit market in Parkistan. Asian Institute of Technology, Division of Human Settlement Development Bangkok, Thailand.

Institute of Statistical, Social and Economic Research (2008). The State of the Ghanaian Economy in 2007, ISSER, University of Ghana pp 28, 128-130.

Kashuliza, A. K., Hella, P., Magayane, F.F., Mvena, Z.S.K. (1998). The role of Informal and Semi-formal Finance in Poverty Alleviation in Tanzania: Results of a field study in two regions of REPOA. Research Report No 98.1.

Khandker, R. S., Faruqee R. R., (2003). The Impact of Farm Credit in Parkistan . Agricultural Economics 28 (2003) 197-213.

Maddala, G.S .(1999). Limited Dependent and Qualitative Variables in Economics, Cambridge University Press. Pp 223-228.

MoFA. (2009). Facts and Figures. Statistics, Research and Information Directorate (SRID) of the Ministry of Food and Agriculture (MoFA), Accra-Ghana, January, 2009.

Mohieldin, S. M, Wright, W.P. (2000). Formal and Informal Credit Market in Egypt: Economic Developemnt and Cultural Change. Vol 48 No. 3 PP 657-670.

Okurut, N., Schoombee, A., Van der Berg, S.(2004). Credit Demand and Credit rationing in the Informal financial Sector in Uganda. African Development and Poverty Reduction: The Macro-Micro Linkage. Forum Paper, Lord Charles 
Dadson Awunyo-Vitor and Vincent Abankwah

Hotel, Somerset West, South Africa.

Pindyck, R. S. Rubinfeld, D. L. (1981). Econometric Models and Economic Forecasts. (2nd ed). McGraw- Hill Book Co. New York.

Steel, F. W., Andah, O. D., (2004). Rural and Micro Finance Regulation in Ghana: Implications for development of the Industry. Publication for proceedings of conference on Ghana at Half Century.

Steiner, S. (2008). Determinants of the use of financial services in rural Ghana:

Implications for social protection, Brooks World Poverty Institute, University of Manchester.

Udry, C. (1990). Credit markets in Northern Nigeria: Credit as insurance in a rural economy. World Bank Economic Review 4(3): 251-269.

Zeller, M. (1994). Determinants of Credits Rationing: A study of informal lenders and formal credit groups in Madagascar. World Development 22(12): 1895-1907. 